\title{
Versatile use of the posterior interosseous flap in the reconstruction of complex upper limb defects
}

\author{
Ensar Zafer Barın, M.D.,' $\odot$ Hakan Çinal, M.D.,' ${ }^{1}$ Murat Kara, M.D., ${ }^{2}$ \\ Mehmet Akif Çakmak, M.D., ${ }^{1}$ CÖ Öder Tan, M.D.'
}

\begin{abstract}
1Department of Plastic Reconstructive and Aesthetic Surgery, Ataturk University, Faculty of Medicine, Yakutiye, Erzurum-Turkey
${ }^{2}$ Department of Plastic Reconstructive and Aesthetic Surgery, Training and Research Hospital, Yakutiye, Erzurum-Turkey
\end{abstract}

\begin{abstract}
BACKGROUND: Reconstruction of the complex upper extremity defects is a challenging procedure for reconstructive surgeons because of the complex anatomical and functional structure of this region. In reconstruction, local and regional flap options involving the composite tissues are restricted. The posterior interosseous flap (PIO) has been presented "in a single study" with a wide variety of uses, and in this study, the versatility of PIO has been tried to be emphasized by its multitude uses as well as its chance at adaptability to each case. Hence, due to this, the objective to highlight the versatile utility of the PIO flap in clinical practice and to present a good option for the reconstruction of complex upper limb defects for various cases have been targeted.
\end{abstract}

METHODS: We used 26 PIO flaps in 25 patients ( 18 male and seven female patients) with upper limb defects. The main etiological causes were burn contracture, traffic accident, firearm and acute burn injury. Twenty-two flaps were harvested as fasciocutaneous and four flaps as osteo-fasciocutaneous manner, which were applied to the metacarpal defects. In this study, 25 flaps were transferred as pedicled flaps, of which 23 and 2 flaps had reverse and antegrade blood flows, respectively, whereas one flap was used as a free flap.

RESULTS: The mean follow-up period was 14 months. All flaps except one, which had partial necrosis and secondary healed, survived completely. All patients were able to gain basic functions for daily routine activities in the late postoperative period. Patients and/ or their parents were satisfied with the postoperative functional and aesthetic improvements.

CONCLUSION: Many advantages of the PIO flap make it useful for the reconstruction of upper limb complex defects. It can be versatilely used based on changing its flow direction and enrichment of contents.

Keywords: Complex defect; flap; hand; posterior interosseous; upper extremity.

\section{INTRODUCTION}

Complex upper limb defects may be particularly arise from trauma, firearm, burn and tumor resection, either exposing the vital structures, such as tendon, nerve, artery, and bone or accompanying with the defects of these structures. Thus, both circumstances necessitate flap closure. In reconstruction, local and regional flap options involving the above-mentioned composite tissues are restricted. Free flaps usually remain the unique and last option in such defects. However, these applications have also some specific and supplemental risks, which consist of inappropriate recipient vessels for microanastomosis in traumatic limb, prolonged operative time, sophisticated equipment and procedure requirements, and bulky volumes of the transferred tissues.

The posterior interosseous (PIO) flap, which was first described by Zancolli and Angrigiani in 1986, ${ }^{[1,2]}$ has been versatilely used in various styles in the literature, concerning blood flow pattern as antegrade ${ }^{[3]}$ or retrograde, ${ }^{[4]}$ type of transfer as pedicled ${ }^{[4]}$ or free ${ }^{[5]}$ and tissue content as fascial, fasciocutaneous $^{[6]}$ or osteo-fasciocutaneous. ${ }^{[4]}$ This flap is raised

Cite this article as: Barın EZ, Çinal H, Kara M, Çakmak MA, Tan Ö. Versatile use of the posterior interosseous flap in the reconstruction of complex upper limb defects. Ulus Travma Acil Cerrahi Derg 2019;25:597-602.

Address for correspondence: Ensar Zafer Barın, M.D.

Atatürk Üniversitesi Tıp Fakültesi, Plastik, Rekonstrüktif ve Estetik Cerrahi Anabilim Dalı, Erzurum, Turkey

Tel: +90 4423446666 E-mail: ensarzafer@gmail.com

Ulus Travma Acil Cerrahi Derg 2019;25(6):597-602 DOI: 10.14744/tjtes.2019.54889 Submitted: 30.01.2018 Accepted: 08.02.2019 Online: 28.10.2019

Copyright 2019 Turkish Association of Trauma and Emergency Surgery 
from the posterior aspect of the forearm and supplied by cutaneous branches of the posterior interosseous artery. The present study aims to highlight the versatile utility of the flap in clinical practice and to present a good option for the reconstruction of complex upper limb defects.

\section{MATERIALS AND METHODS}

In this study, we used 26 PIO flaps in 25 patients (18 male and seven female patients) with upper limb defects. The main etiological causes were burn contracture, traffic accident, firearm and acute burn injury in eight, six, four and three patients, respectively. The age of patients ranged from three to 66 years (mean 23.2 years). The defect sites were mostly on the hand (23), and on the elbow in two patients. The flap sizes varied from $4 \times 2.5 \mathrm{~cm}$ to $12 \times 7 \mathrm{~cm}$. Twenty-two flaps were harvested as fasciocutaneous and four flaps as osteo-fasciocutaneous manner, which were applied to the metacarpal defects. Twenty-five flaps were transferred as pedicled flaps, of which 23 and two flaps had reverse and antegrade blood flows, respectively, whereas one flap was used as a free flap. The donor sites were closed primary in 19 patients and with split-thickness skin grafts in six patients.

\section{Operative Technique}

The operation was performed under general anesthesia, with the arm on the side table and wrist in full pronation. A straight line was drawn from the lateral epicondyle to the distal radioulnar joint. This line represented the axis of the flap, which showed the trace of the vascular pedicle into the septum between the tendons of the extensor carpi ulnaris and extensor digiti minimi. In reverse flow PIO flap, the pivotal point was marked 2 or $3 \mathrm{~cm}$ proximal to the distal radioulnar joint, whereas it was marked on the proximal radioulnar joint in antegrade flow PIO flap. The required length of the pedicle was then measured from the pivotal point to the proximal edge of the defect. The skin paddle was placed proximally and distally on the flap axis in reverse flow and antegrade flow PIO flaps, respectively. The dissection was started at the vascular pedicle and continued towards the skin paddle. It was important to make sure that the posterior interosseous artery and its concomitant veins existed in the septum. In case of the absence of the vascular pedicle, the procedure would be aborted, and alternate flaps would be used. At this point, the posterior interosseous nerve, which was very close to the artery, was identified and protected. The skin paddle was then raised over the deep muscle fascia in a fasciocutaneous manner. In the reconstruction of bone defects, a longitudinal ulna segment was included in the flap. The flap was transferred to the defect site through the subcutaneous tunnel, which had to be wide enough to avoid compression or torsion of the pedicle. The free PIO flap was designed and harvested in the same manner with the antegrade flow PIO flap.

\section{RESULTS}

The mean follow-up period was 14 months. All flaps except one, which had partial necrosis and secondary healed and survived completely. There were no additional complications, such as wound dehiscence, infection, and hematoma. We did not encounter "drop hand" deformity due to the PIO nerve injury during pedicle dissection in any patient. No patient required late surgical revision for debulking. In osteo-fasciocuta-
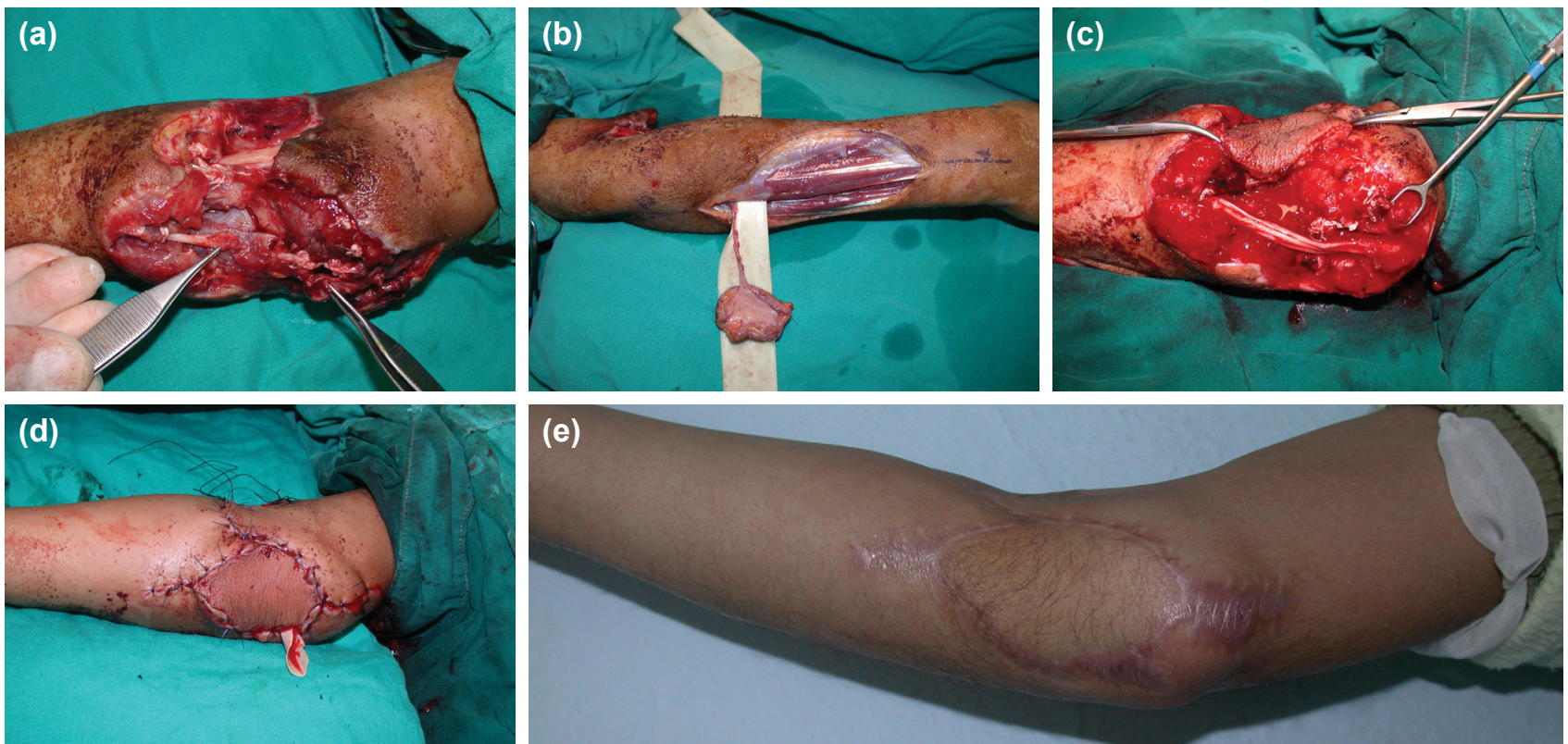

Figure 1. A 15-year-old male patient suffered from a complex soft tissue defect located on the right elbow due to traffic accident. (a) Preoperative view showing the ulnar nerve defect. (b) Raising of the antegrade flow PIO fap of $6 \times 5 \mathrm{~cm}$ so as to pass between the radius and ulna where a penrose drain was placed. (c) Transfer of the flap to the defect site. The ulnar nerve defect was repaired with interpositional sural nerve grafts consisted of three cables. (d) Closure of the defect. (e) Late postoperative view of 11 months. 
neous flaps, there were no usual bone-related complications such as non-union, mal-union, bone resorption, or secondary fracture. The average time of bone union was three months and all donor bones (ulna) were healed with no fractures. Recoveries of the skin donor sites were uneventful in our series. All patients were able to gain basic functions for daily routine activities in the late postoperative period. Patients and/or their parents were satisfied with the postoperative functional and aesthetic improvements.

The case samples that presented with various complex upper extremity defects are demonstrated in Figures I to 3.
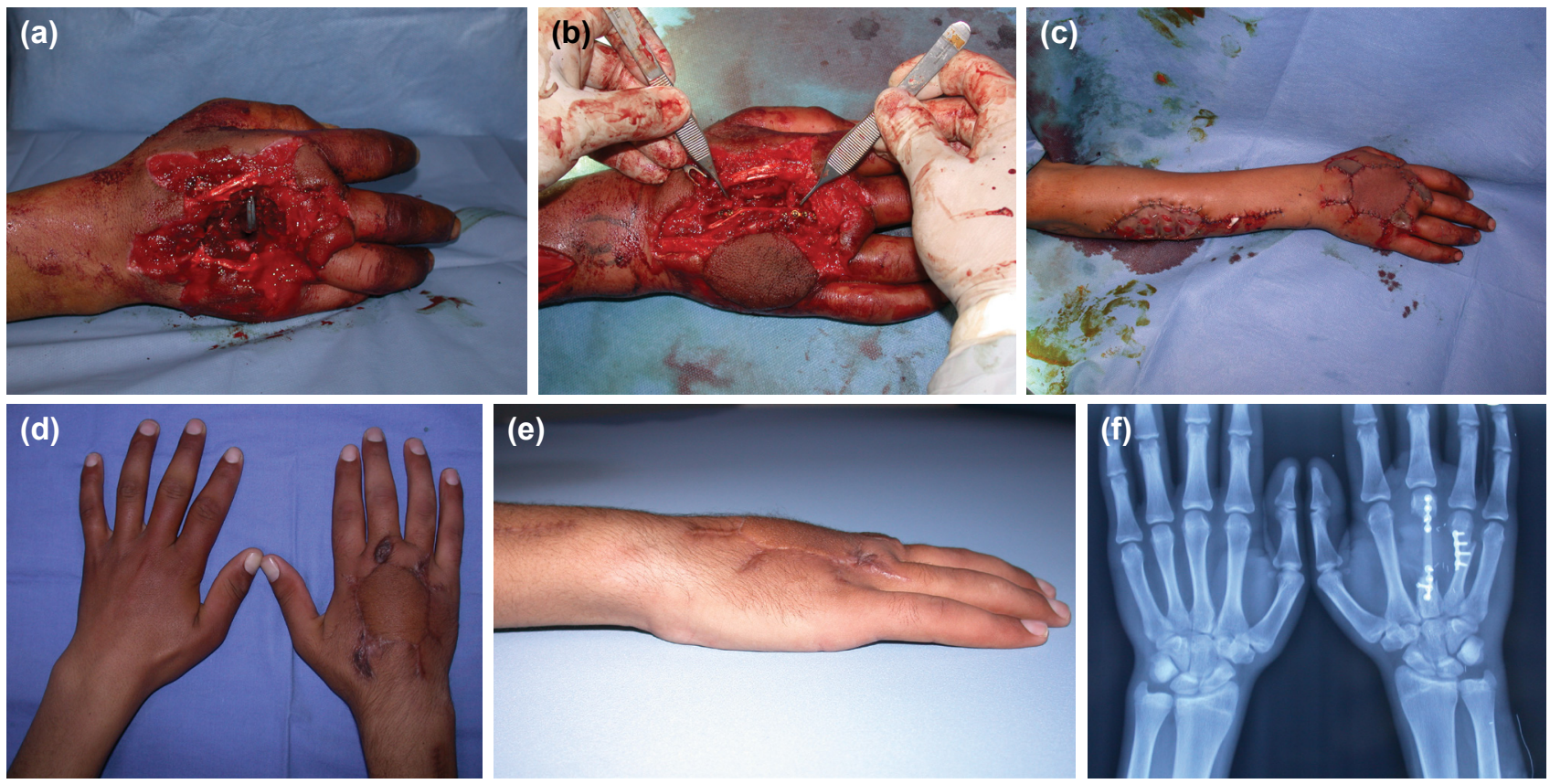

Figure 2. An 18-year-old male patient presented with a complex hand wound including the soft tissues and third metacarpal, caused by a firearm. The composite osteofasciocutaneous PIO flap was planned for reconstruction. (a) Preoperative dorsal aspect. A surgical clamp was easily placed through the defect from volar to dorsal side. (b) Inset of the flap in the recipient site. Metacarpal was restored with the ulna segment of the composite PIO flap. (c) Intraoperative early aspect of the defect and donor sites. (d) Postoperative comparative aspect of both hands. (e) The PIO flap provided a good contour and a thin coverage on the dorsum of the hand. (f) Postoperative radiographic aspect of the metacarpal substitution.

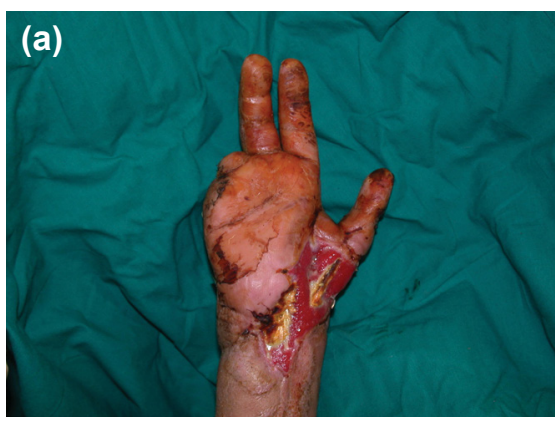

(d)

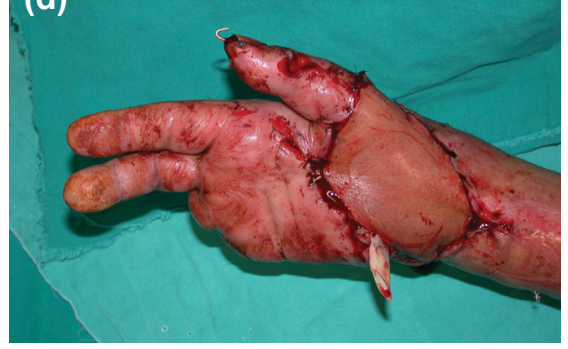

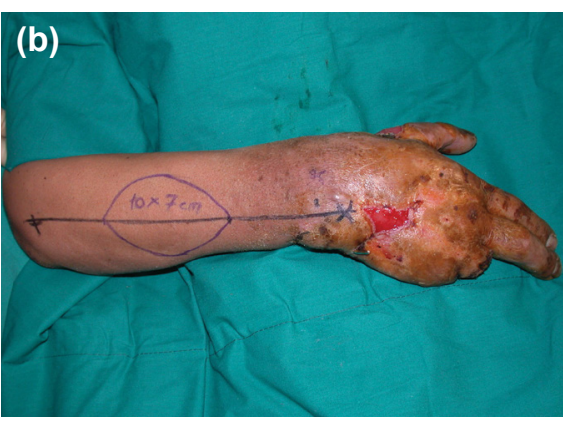

(e)

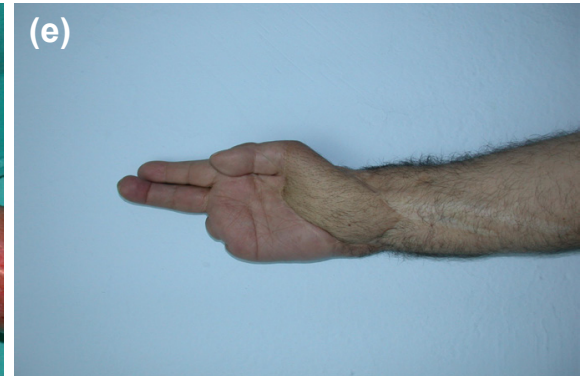

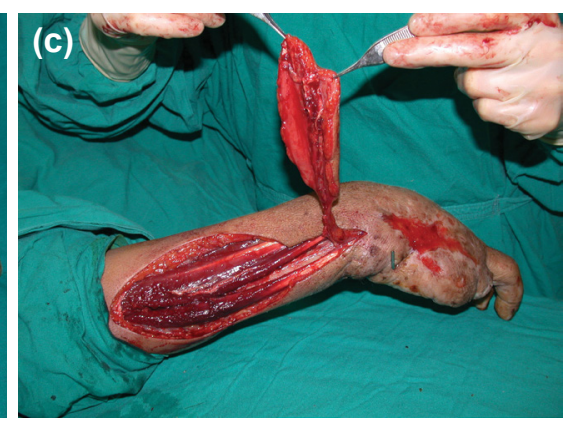

(f)

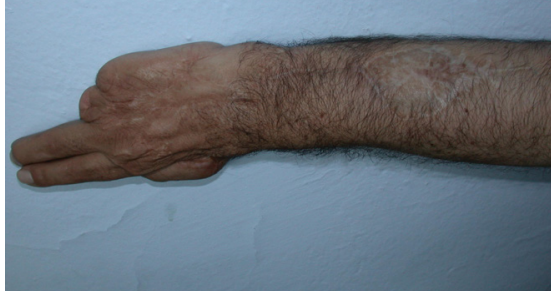

Figure 3. A 48-year-old male patient had a complex soft tissue defect exposing the tendons on the volar side of the hand and wrist, caused by agriculture machine. A large reverse flow PIO flap, which was $12 \times 7 \mathrm{~cm}$ in size, was designed. (a) Preoperative appearance of the defect. (b) Design and marking of the flap. (c) Elevation of the flap. (d) Inset of the flap in the recipient site. (e) Late postoperative volar appearance of 2.5 years. (f) Late postoperative dorsal appearance showing the donor site which was covered with skin graft. 


\section{DISCUSSION}

Reconstruction of the complex upper extremity defects is a challenging procedure for reconstructive surgeons because of the complex anatomical and functional structure of this region. Ideal repair should be performed from hard to soft tissues and from deep to surface planes in the least operative session as possible. Thus, it needs restorations of bones, tendons, nerves, and vessels, and then soft tissue coverage, depending on the requirements. Primary repair is ideal, but grafts should be used, if required, for restorations of all these components. Skin coverage is preferred to be pliable, thin and to have good colour and texture match.

Free anterolateral thigh (ALT) flap may be a good option for the reconstruction of the large and complex defects of the upper limb. ${ }^{[7,8]}$ Huge skin islands can be elevated from the thigh to close the large defects exposing the tendons, nerves and bones in this region. Free ALT flap is a right versatile flap since it can be harvested with the tendon of tensor fascia lata for a vascularized tendon reconstruction, ${ }^{[9]}$ with the vastus lateralis muscle to fill dead spaces, ${ }^{[10]}$ or with the lateral femoral cutaneous nerve for the neurotization of the transferred skin paddle. ${ }^{\left[{ }^{\prime \prime}\right]}$

Osteocutaneous free fibular flap is another alternative for the reconstruction of the complex upper limb defects. ${ }^{[12]}$ Fibula is a tubular bone and can be suitable for the reconstruction of long and large-sized bone defects as in humerus, but not for smaller bones, such as radius and ulna. On the other hand, vascular variability, short pedicle, poor nourishment of the skin paddle, difficult dissection and risk of peroneal nerve injury are disadvantages of the fibula flap.

Other free flaps, which were less used in the reconstruction of upper limb defects, were also reported in the literature. Serratus anterior adipofascial flap and vascularized rib flaps can be elevated on the same pedicle. ${ }^{[13,14]}$ Dorsalis pedis fasciocutaneous flap has been also used in the reconstruction of the hand defects ${ }^{[15]}$ with poor donor scar on the foot dorsum.

The reverse flow radial forearm flap, which is known as Chinese flap, has been the main flap choice for years in complex defects of the hand. ${ }^{[16,17]}$ Moderate to large defects of the hand can be successfully reconstructed with this flap. It is thin, pliable and distally based flap and does not need microsurgical expertise. A radial bone segment can also be harvested with the flap. However, the reverse radial forearm flap has lost its popularity because it has some disadvantages, such as the sacrifice of a major artery of the hand and poor donor site scar. ${ }^{[18]}$ The ulnar artery forearm flap is also not commonly used because of similar disadvantages. ${ }^{[19]}$ Dorsoulnar perforator flap is another regional alternative in soft tissue reconstruction. ${ }^{[20,21]}$ Although this flap does not sacrifice the ulnar artery, the limited arc of rotation confines its use to only the proximal palm and ulnar side of the dorsal hand.
The pedicled groin and abdominal flaps have been utilized in many studies. ${ }^{[22]}$ However, multi-staged procedure and bulky structure are the main disadvantages of these techniques.

Since 1986, when the PIO flap has been first reported by Zancolli and Angrigiani, ${ }^{[2]}$ it has been used in several types of transfer as a right versatile flap. Park et al. have reported the free transfer of the PIO flap in their series. ${ }^{[5]}$ Akın et al. treated metacarpal bone and soft tissue defects on the hand with an osteocutaneous PIO flap in five patients. ${ }^{[23]}$ Mazzer used this flap based on antegrade flow in two cases. ${ }^{[3]} \mathrm{We}$, firstly, utilized the PIO flap in all reported manners in the same series in the literature.

The PIO flap has considerable advantages when compared to the remaining regional flaps, including constant and long vascular pedicle, wide arc of rotation, good colour and texture match, thin and pliable skin paddle, versatile contents, such as skin, fascia, and bone segment, easy dissection, and short operative time. The pedicled PIO flap can be transferred on its distal and proximal bases for the coverage of hand and wrist, and elbow and distal arm defects, respectively. Moreover, the microvascular transfer is also possible for the PIO flap. Regional anesthesia alone can be mostly enough during the whole operative procedure. The main arteries of the upper limb are protected with the harvest of this flap.

The PIO flap has been proved to be quite safe in the reported studies. Necrosis rates of the PIO flap ranged between $8.8 \%$ and 28.5\%. ${ }^{[24-28]}$ Büchler and Frey suggested that the main reason for the necrosis of the PIO flap was arterial ischemia, ${ }^{[24]}$ whereas, Shibata blamed hypoplasia of the distal anastomosis between the posterior and the anterior interosseous arteries. ${ }^{[25]}$ Tan reported no flap necrosis in his PIO flap series comprising 10 children. ${ }^{[4]}$ Büchler and Frey found partial flap necrosis in 21 percent of their series and ascribed this to arterial ischemia (7I percent) or venous congestion (29 percent). ${ }^{[2]}$ Costa et al. reported two patients with rim necrosis in 21 pedicled PIO flap transfers. ${ }^{[26]}$ Angrigiani et al. described four total flap failures and three partial necroses (8.8 percent) in 80 consecutive patients. ${ }^{[27]}$ They concluded that insufficient vascularization had resulted in flap failure. It has been reported that the planning of the flap skin island to reach the 1/3 distal of the forearm would reduce venous congestion. ${ }^{[29]}$ Sonmez et al. reported an alternative solution for venous congestion in a superficial vein anastomosis added to the PIO flap. ${ }^{\left[{ }^{30]}\right.}$ Furthermore, Nikkhah et al. reported in his study that small technical manoeuvres had been conducted for the safe removal of the flap. ${ }^{[3]}$ In our series, there was one partial necrosis, which healed as secondary with no intention. Partial or total necrosis rates were lower in our series compared to the literature, because of the extremely rigorous pedicle dissection and minimization of conditions such as kinging or compression that may occur in the vascular pedicle. 
The largest PIO flap reported in the literature was $16 \times 10$ $\mathrm{cm} \cdot{ }^{[32]}$ In our series, the largest PIO flap was $12 \times 7 \mathrm{~cm}$ in dimension. One of the major handicaps of the PIO flap is insufficiency in coverage of large to huge defects. Similarly, in the distal proximal interphalangeal joint (PIF), the PIO flap is also insufficient in extreme tissue defects, including the dorsal or volar faces of the fingers. In the study by Zaidenberg et al., which described the flaps planned to use the dorsal intercarpal arch (DIA) and posterior interosseous artery (PIA) anastomoses might be the solution to distal tissue defects in which the classical PIO flap is inadequate. ${ }^{[33]}$

The donor site scar can also be observed as another problem in PIO flaps. The donor site scars are acceptable, particularly in primary closure. However, in some cases, a graft may be used for donor site repair. In our series of 25 patients, the donor site of six patients (24\%) was closed with STSG. Although this ratio has been reported up to $50 \%$ in the literature, the closure of the donor site with the graft is directly related to the width of the flap removed. ${ }^{[34]}$ As an alternative to the donor site problem, Çoban et al. has proposed a triangular design and has suggested $\mathrm{V}-\mathrm{Y}$ closure ${ }^{[35]}$ Jakubietz and colleagues presented the removal of the flap as a facial component, without skin, as a solution to the donor site problem. ${ }^{[36]}$ As to the donor site scar, patient and parent satisfaction is at an acceptable level in our series and to support this point; it has been reported in the literature that PIO flap is an acceptable option according to the other flap alternatives in which the forearm is used as a donor site. ${ }^{[2]}$

Although there have been reports of temporal motor paralysis due to posterior interosseous nerve damage in the literature, no patient in our series had a wrist drop or similar complication due to a PIN wound.

In conclusion, many advantages of the PIO flap make it useful for the reconstruction of the upper limb complex defects. PIO flap can be versatilely used based on its flow direction and contents. The PIO flap presents a good alternative for free flaps, particularly in the lack of microsurgical background.

Conflict of interest: We disclose that there are no financial and personal relationships with other people or organisations that could inappropriately influence (bias) this study.

\section{REFERENCES}

1. Zancolli EA, Angrigiani C. Colgajo dorsal de antebrazo (en isla); Forearm dorsal. Rev Asoc Argent Ortop Traumatol 1986;51:161-8.

2. Zancolli EA, Angrigiani C. Posterior interosseous island forearm flap. J Hand Surg Br 1988;13:130-5. [CrossRef]

3. Mazzer N, Barbieri $\mathrm{CH}$, Cortez $\mathrm{M}$. The posterior interosseous forearm island flap for skin defects in the hand and elbow. A prospective study of 51 cases. J Hand Surg Br 1996;21:237-43. [CrossRef]

4. Tan O. Reverse posterior interosseous flap in childhood: a reliable alternative for complex hand defects. Ann Plast Surg 2008;60:618-22.
5. Park JJ, Kim JS, Chung JI. Posterior interosseous free flap: various types. Plast Reconstr Surg 1997;100:1186-97. [CrossRef]

6. Goubier JN, Romana C, Masquelet AC. [The posterior interosseous flap in the child: 13 case reports]. Chir Main 2002;21:102-6. [CrossRef]

7. Yazar S, Gideroglu K, Kilic B, Gokkaya A. Use of composite anterolateral thigh flap as double-vascularised layers for reconstruction of complex hand dorsum defect. J Plast Reconstr Aesthet Surg 2008;61:1549-50.

8. Meky M, Safoury Y. Composite anterolateral thigh perforator flaps in the management of complex hand injuries. J Hand Surg Eur Vol 2013;38:366-70. [CrossRef]

9. Houtmeyers P, Opsomer D, Van Landuyt K, Monstrey S. Reconstruction of the Achilles tendon and overlying soft tissue by free composite anterolateral thigh flap with vascularized fascia lata.J Reconstr Microsurg 2012;28:205-9. [CrossRef]

10. Cordova A, D’Arpa S, Di Lorenzo S, Toia F, Campisi G, Moschella F. Prophylactic chimera anterolateral thigh/vastus lateralis flap: preventing complications in high-risk head and neck reconstruction. J Oral Maxillofac Surg 2014;72:1013-22. [CrossRef]

11. Baas M, Duraku LS, Corten EM, Mureau MA. A systematic review on the sensory reinnervation of free flaps for tongue reconstruction: Does improved sensibility imply functional benefits? J Plast Reconstr Aesthet Surg 2015;68:1025-35. [CrossRef]

12. Momeni A, Stark GB. The free fibular flap: a useful flap for reconstruction following composite hand injuries. J Hand Surg Br 2006;31:3045. [CrossRef]

13. Fassio E, Laulan J, Aboumoussa J, Senyuva C, Goga D, Ballon G. Serratus anterior free fascial flap for dorsal hand coverage. Ann Plast Surg 1999;43:77-82. [CrossRef]

14. Siotos C, Neira PM, Lau BD, Stone JP, Page J, Rosson GD, et al. Origins of Gender Affirmation Surgery: The History of the First Gender Identity Clinic in the United States at Johns Hopkins. Ann Plast Surg 2019;83:132-6. [CrossRef]

15. Caroli A, Adani R, Castagnetti C, Pancaldi G, Squarzina PB. Dorsalis pedis flap with vascularized extensor tendons for dorsal hand reconstruction. Plast Reconstr Surg 1993;92:1326-30.

16. Soucacos PN, Zoubos AB, Korompilias AV, Vekris MD. Versatility of the island forearm flap in the management of extensive skin defects of the hand. Injury 2008;39:S49-56.

17. Kaufman MR, Jones NF. The reverse radial forearm flap for soft tissue reconstruction of the wrist and hand. Tech Hand Up Extrem Surg 2005;9:47-51. [CrossRef]

18. Brunelli F, Valenti P, Dumontier C, Panciera P, Gilbert A. The posterior interosseous reverse flap: experience with 113 flaps. Ann Plast Surg 2001;47:25-30. [CrossRef]

19. Liu DX, Wang H, Li XD, Du SX. Three kinds of forearm flaps for hand skin defects: experience of 65 cases. Arch Orthop Trauma surg 2011;131:675-80. [CrossRef]

20. Uygur F, Uygur M, Ulkur E, Sever C. Versatility of the reverse dorsoulnar fasciocutaneous flap in coverage of hand defects: clinical experience with 36 cases. J Hand Surg Am 2009;34:1327-33. [CrossRef]

21. Tan O, Kilic M. Supercharged dorsoulnar island flap: a case report and review of the literature. Acta Orthop Traumatol Turc 2011;45:53-7.

22. Sabapathy SR, Bajantri B. Indications, selection, and use of distant pedicled flap for upper limb reconstruction. Hand Clin 2014;30:185-99.

23. Akin S, Ozgenel Y, Ozcan M. Osteocutaneous posterior interosseous flap for reconstruction of the metacarpal bone and soft-tissue defects in the hand. Plast Reconstr Surg 2002;109:982-7. [CrossRef]

24. Büchler U, Frey HP. Retrograde posterior interosseous flap. J Hand Surg Am 1991;16:283-92. [CrossRef] 
25. Shibata M, Iwabuchi Y, Kubota S, Matsuzaki H. Comparison of free and reversed pedicled posterior interosseous cutaneous flaps. Plast Reconstr Surg $1997 ; 99: 791-802$. [CrossRef]

26. Costa H, Comba S, Martins A, Rodrigues J, Reis J, Amarante J. Further experience with the posterior interosseous flap. Br J Plast Surg 1991;44:449-55. [CrossRef]

27. Angrigiani C, Grilli D, Dominikow D, Zancolli EA. Posterior interosseous reverse forearm flap: experience with 80 consecutive cases. Plast Reconstr Surg 1993;92:285-93. [CrossRef]

28. Akinci M, Ay S, Kamiloglu S, Erçetin O. The reverse posterior interosseous flap: A solution for flap necrosis based on a review of 87 cases. J Plast Reconstr Aesthet Surg 2006;59:148-52. [CrossRef]

29. Akdag O, Yildiran G, Sutcu M, Karameșe M. Posterior interosseous flap versus reverse adipofascial radial forearm flap for soft tissue reconstruction of dorsal hand defects. Ulus Travma Acil Cerrahi Derg 2018;24:43-8.

30. Sonmez E, Aksam E, Durgun M, Karaaslan O. Venous super-drained posterior interosseous artery flap for dorsal hand defects. Microsurgery 2018;38:876-81. [CrossRef]
31. Nikkhah D, Pickford M. Techniques to enable identification and safe elevation of the posterior interosseous artery flap. J Plast Reconstr Aesthet Surg 2018;71:1816-34. [CrossRef]

32. Lu L-j, Gong X, Lu X-m, Wang KL. The reverse posterior interosseous flap and its composite flap: Experience with 201 flaps. J Plast Reconstr Aesthet Surg 2007;60:876-82. [CrossRef]

33. Zaidenberg EE, Farias-Cisneros E, Pastrana MJ, Zaidenberg CR. Extended Posterior Interosseous Artery Flap: Anatomical and Clinical Study. J Hand Surg Am 2017;42:182-9. [CrossRef]

34. Neuwirth M, Hubmer M, Koch $H$. The posterior interosseous artery flap: clinical results with special emphasis on donor site morbidity. J Plast Reconstr Aesthet Surg 2013;66:623-8. [CrossRef]

35. Coban YK, Gumus N, Cetinus E. Triangular design and V-Y closure of donor site of posterior interosseous artery flap. Plast Reconstr Surg. 2004;114:264. [CrossRef]

36. Jakubietz RG, Bernuth S, Schmidt K, Meffert RH, Jakubietz MG. The Fascia-Only Reverse Posterior Interosseous Artery Flap. J Hand Surg Am 2019;44:249.e1-9.e5. [CrossRef]

\section{ORİJINAL ÇALIŞMA - ÖZET}

\section{Karmaşık üst uzuv defektlerinde 'posterior interosseöz flebin' çok yönlü kullanımı \\ Dr. Ensar Zafer Barın, ${ }^{1}$ Dr. Hakan Çinal, ${ }^{1}$ Dr. Murat Kara, ${ }^{2}$ Dr. Mehmet Akif Çakmak, ${ }^{1}$ Dr. Önder Tan, ${ }^{1}$ \\ ${ }^{1}$ Atatürk Üniversitesi Tıp Fakültesi, Plastik, Rekonstrüktif ve Estetik Cerrahi Anabilim Dalı, Erzurum \\ ${ }^{2}$ Bölge Eğitim ve Araştırma Hastanesi, Plastik, Rekonstrüktif ve Estetik Cerrahi Kliniği, Erzurum}

AMAÇ: Üst ekstremitenin kompleks anatomik ve fonksiyonel yapısı, bu bölgeye ait kompleks defektlerin onarımının rekonstrüktif cerrahlar için zor bir işlem olmasına neden olmaktadır. Bu rekonstrüksiyonda kompozit dokuları içeren lokal ve bölgesel flep seçenekleri kısıtlıdır. Bu çalışmadaki amaç; posteriyor interosseöz flebinin (PiO) klinik pratikte çok yönlü kullanılabilirliğini vurgulamak ve kompleks üst ekstremite defektlerinde iyi bir seçenek olduğunu belirtmektir.

GEREÇ VE YÖNTEM: Çalışmada üst ekstremite defekti mevcut I8'i erkek, 7'si kadın toplam 25 hastaya, 26 PiO flebi uygulandı. Başlıca etyolojik faktörler, yanık kontraktürü, trafik kazası, ateşli silah yaralanması ve akut yanık yaralanması idi. 22 flep fasyokutanöz kaldırılrken, 4 flep osteofasyokutanöz şekilde kaldırılarak metakarp defektlerine uygulandı. Pediküllü transfer edilen 25 flebin, 23'ü ters, 2'si ise düz akımlı idi. Bir flep ise serbest flep olarak transfer edildi.

BULGULAR: Ortalama takip süresi I4 ay idi. Parsiyel nekroz ve sekonder iyileşme ile düzelen I flep hariç geri kalan fleplerin tamamı bütünüyle sorunsuz iyileşti. Tüm hastalar geç postoperatif dönemde günlük işlerini sürdürebilecek temel fonksiyonları kazandılar. Hastalar ve/veya anne babaları postoperatif fonksiyonel ve estetik gelişimden memnun kaldılar.

TARTIŞMA: PIO flebinin birçok avantajı, üst ekstremite kompleks defektlerinde kullanılabilir olmasını sağlamaktadır. Akım yönünün değiştirilebilirliği ve içeriğinin zenginleştirilebilmesi sayesinde çok yönlü olarak kullanılabilir.

Anahtar sözcükler: Flep; el; kompleks defekt; posteriyor interosseöz; üst ekstremite.

Ulus Travma Acil Cerrahi Derg 2019;25(6):597-602 doi: 10.14744/tjtes.2019.54889 